\title{
Combined effect of crude fat content and initial substrate concentration on batch anaerobic digestion characteristics of food waste
}

\author{
Wanqin Zhang a,b, Qianqian Lang ${ }^{\mathrm{c}}$, Ming Fang ${ }^{\mathrm{d}}$, Xin Li ${ }^{\mathrm{b}}$, Hamidou Bah ${ }^{\mathrm{e}}$, Hongmin Dong ${ }^{\mathrm{a}}$, Renjie Dong ${ }^{\mathrm{b}, *}$ \\ ${ }^{a}$ Institute of Environment and Sustainable Development in Agriculture, Chinese Academy of Agricultural Sciences, Beijing 100081, PR China \\ ${ }^{\mathrm{b}}$ College of Engineering (Biomass Engineering Center), China Agricultural University, Beijing 100083, PR China \\ ${ }^{\mathrm{C}}$ Research Center for Eco-Environmental Sciences, Chinese Academy of Sciences, 18 Shuangqing Road, Beijing 100085, PR China \\ ${ }^{\mathrm{d}}$ Tus-Sound Environmental Resources Co., Ltd, Beijing 101102, PR China \\ ${ }^{\mathrm{e}}$ Institute Superior Agronomy and Veterinary of Faranah (ISAV/F), Faranah 131, Guinea
}

\section{H I G H L I G H T S}

- AD character of food waste (FW) with different crude fat contents was evaluated.

- FW with $30 \%$ crude fat (CF) with $4 \mathrm{gVS} / \mathrm{L}$ achieved the maximum methane yield.

- At loading of 8 and $10 \mathrm{gVS} / \mathrm{L}, 35 \% \mathrm{CF}$ content inhibited methane production.

- The $\lambda$ was extended with the CF contents and substrate concentrations increased.

- $35 \% \mathrm{CF}$ decreased the first-order degradation constant by approximately $40 \%$.

\section{A R T I C L E I N F O}

\section{Article history:}

Received 29 December 2016

Received in revised form 8 February 2017

Accepted 9 February 2017

Available online 24 February 2017

\section{Keywords:}

Food waste

Anaerobic digestion

Crude fat content

Initial substrate concentration

Kinetic study

\section{G R A P H I C A L A B S T R A C T}

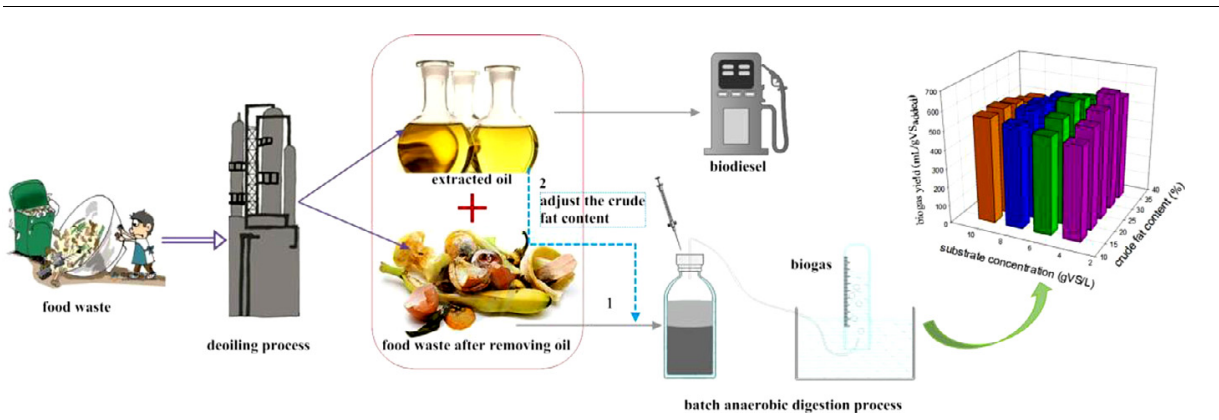

\begin{abstract}
A B S T R A C T
The mesophilic anaerobic digestion (AD) characteristics of food waste (FW) with different crude fat (CF) contents and four initial substrate concentrations $(4,6,8$, and $10 \mathrm{gVS} / \mathrm{L})$ were investigated. The maximum methane yields of FW with CF contents of $15 \%, 20 \%, 25 \%, 30 \%$, and 35\% were 565.0, 580.2, 606.0, 630.2 and $573.0 \mathrm{~mL} \mathrm{CH}_{4} / \mathrm{gVS}_{\text {added, }}$, respectively. An acidification trend with a drop in $\mathrm{pH}(<6.80)$ and increase in the volatile fatty acids/total inorganic carbon (VFAs/TIC) ratio $(>0.4)$ were found for CF contents of $30 \%$ $(10 \mathrm{gVS} / \mathrm{L})$ and 35\% ( 8 and $10 \mathrm{gVS} / \mathrm{L})$. A 35\% CF content in FW led to decrease in the first-order degradation constant of approximately by $40 \%$. The modified Gompertz model showed that the lag phase $(\lambda)$ was prolonged from 0.4 to 7.1 days when the CF content in FW and initial substrate concentration were increased to $35 \%$ and $10 \mathrm{gVS} / \mathrm{L}$.
\end{abstract}

(c) 2017 Elsevier Ltd. All rights reserved.

\section{Introduction}

The management of food waste (FW) has become an important issue in recent years throughout the world. As reported, the annual

\footnotetext{
* Corresponding author.

E-mail addresses: zhang394982409@126.com (W. Zhang), rjdong@cau.edu.cn (R. Dong).
}

output of FW in USA, EU-27, and Japan, accounts to around 26, 50, and 20 million tons, respectively (Wu et al., 2011). Especially in China, according to China Statistical Yearbook 2011, 60 million tons of FW was generated per year with the annual increasing rate higher than $10 \%$, and less than $20 \%$ of this waste was properly treated (Zhang et al., 2016). Different from the organic fraction of other forms of solid wastes, FW contains a higher level of crude fat (CF), which is defined as fat, oil, and grease (FOG). In addition, CF could 
achieve a higher theoretical methane yield $(1000 \mathrm{~mL} / \mathrm{gVS})$ than carbohydrates (373 mL/gVS) and proteins (480 mL/gVS) (Cho et al., 2013; Pastor et al., 2013; Wellinger et al., 2013). On the basis of the high biodegradability and biomethane production potential of FW, anaerobic digestion (AD) has become an alternative technology with its dual benefits of stabilizing organic waste and recovering energy from FW (Li et al., 2016; Niu et al., 2013).

Currently, the AD of FW is attracting strong interest, and many studies including adding trace elements, co-digestion, pretreatments on the methane fermentation of FW have been performed recently. However, these studies indicated that high $\mathrm{CF}$ content in FW is a main limiting factor for stable operation of full-scale FW biogas plants. During the AD process, CF is initially catalysed to glycerol and long-chain fatty acids (LCFAs) by lipase. Then, the LCFAs are further transformed to hydrogen, $\mathrm{CO}_{2}$, and acetate (or propionate) via $\beta$-oxidation pathway, which has been reported as the rate-limiting step of the entire AD process (Angelidaki and Ahring, 1992; Noutsopoulos et al., 2013). On the one hand, appropriate CF could increase the methane yield of anaerobic digester due to its high biomethane production potential. Sompong et al. (2012) reported that co-digestion of oil palm empty fruit bunches (EFB-oil: 1.1\%TS) with palm oil mill effluent (POME-oil: $12.5 \% \mathrm{TS}$ ) resulted in a $25-32 \%$ higher methane production at mixing ratios of $0.4: 1-2.3: 1$ on a VS basis (based on volatile solids) compared with digesting EFB alone.

On the other hand, LCFAs produced by CF were toxic to the microorganisms, such as hydrogen-producing acetogenic bacteria and acetotrophic and hydrogenotrophic methanogens, even at low concentrations (Cho et al., 2013; Kafle and Kim, 2013; Kim et al., 2004). Furthermore, the adsorption of LCFAs onto biomass also caused various operational problems such as biological bulking, foaming, flotation, oxygen mass-transfer difficulties, odours, and increased effluent concentrations of organic matter, as well as clogging of the gas and effluent lines (Cirne et al., 2007; Noutsopoulos et al., 2013). Many methods have been evaluated in attempts to minimize the negative effects caused by LCFAs. These strategies include the co-digestion of fat-rich matter with other organic matter (Pastor et al., 2013; Sompong et al., 2012), addition of absorbents (bentonite powder and fibers) (Palatsi et al., 2009), use of the novel anaerobic flotation reactors, and removal of CF prior to AD operation (Cho et al., 2013; Gumisiriza et al., 2009). Gumisiriza et al. (2009) found that the removal of $\mathrm{CF}$ prior to $\mathrm{AD}$ enhanced the production of methane by $52 \%$ from fish processing wastewater.

Actually, CF is a good material for producing biodiesel (Zhang et al., 2003). Thus, in order to improve the economic feasibility and the operation stability of the $\mathrm{AD}$ process for treating $\mathrm{FW}$, part of the $\mathrm{CF}$ prior to $\mathrm{AD}$ could be extracted from collected domestic FW. In addition, for a practical biogas plant using FW as the main material, the hydraulic retention time (HRT) could be shortened after the CF was extracted. Besides the CF content, consideration of the variable seasonal FW output, the substrate concentration is another important factor that influences the efficiency of $A D$ (Dhar et al., 2015; Raheman and Mondal, 2012; Zhang et al., 2014). On the basis of methanogens' metabolic activity, certain studies have been performed on how CF enhances or inhibits methane production. However, one side, in the site of FW biogas plants, how much CF should be kept in raw FW for biogas production is not clear. On the other side, the available information on the $\mathrm{AD}$ of FW with different CF contents is quite limited in terms of the effect of the initial substrate concentrations.

This study aimed to investigate the AD characteristics of FW with various $\mathrm{CF}$ contents and initial substrate concentrations. The methane yields of FW with different CF contents at four substrate concentrations were evaluated. Furthermore, the first-order kinetic model and modified Gompertz model were introduced to fit the experimental results and predict the methane yields of each FW sample in AD. Moreover, linear and non-linear regression curves were developed to assist in the interpretation of the results. The results obtained from this study will provide valuable fundamental information for future research and acquiring renewable energy from FW.

\section{Methods}

\subsection{Substrates and inoculum}

The FW used in this study was collected from a restaurant in Beijing, China. Firstly, the non-biodegradable contaminants in the FW were removed by hand, then the FW was crushed using an electrical kitchen blender (JYL-A100, Jinan, China). The CF (oil, fat, and grease) in FW was extracted using the method described by Lalman and Bargely (Lalman and Bagley, 2004). The fat extracted FW was frozen at $-20^{\circ} \mathrm{C}$ to prevent biological decomposition, and the frozen substrates were thawed in a refrigerator at $4{ }^{\circ} \mathrm{C}$ for 1 day before they were used. The inoculum (seed sludge) was collected from an anaerobic digester in the Xiaohongmen municipal wastewater treatment plant located in Beijing, China. The characteristics of the original and CF extracted FW and inoculum are listed in Table 1. Simultaneously, the characteristics of FW used in this study were compared with that taken from other regions of the world (Banks and Zhang, 2010; Qiang et al., 2012).

\subsection{Batch digester start-up and experimental design}

The batch digestion test was performed in $250 \mathrm{~mL}$ serum bottles capped with natural rubber sleeve stoppers. The working volume of the bottle was $180 \mathrm{~mL}$. In order to keep the physicochemical properties constant, fat-extracted FW was used as the basic substrate, and the CF contents of the fermentation substrate were adjusted to $15 \%, 20 \%, 25 \%, 30 \%$, and $35 \%$ using the extracted CF according to the Eq. (1). Different VS (volatile solids) concentrations of the substrates were required to determine the degradation characteristics of FW samples with different concentration of CF. The initial fermentation concentration was $4.0 \%$, $6.0 \%, 8.0 \%$ and $10.0 \%$ of VS (corresponding to initial substrate concentrations of $4,6,8$ and $10 \mathrm{gVS} / \mathrm{L}$, respectively), respectively, in this test. Firstly, according to the substrate concentrations, different amounts of FW samples were added to each bottle. The feed to inoculum (F/I) ratio was maintained at 0.5 according to the suggested value ( $F / I=0.5-2.0)$ by Kafle et al. (2014). Then, appropriate volume distilled water was added to the bottle for a final volume of $180 \mathrm{~mL}$. Subsequently, the initial $\mathrm{pH}$ of the mixed liquor in each digester was adjusted to $7.0 \pm 0.1$ by using $1 \mathrm{~mol} / \mathrm{L} \mathrm{HCl}$ or $1 \mathrm{~mol} / \mathrm{L}$ $\mathrm{NaOH}$ (Zhang et al., 2014). The headspace of the bottles were flushed with $100 \%$ pure nitrogen for approximately 2 min to ensure anaerobic conditions (Kafle et al., 2013). The anaerobic digesters were maintained at $37 \pm 1^{\circ} \mathrm{C}$ in a temperature-controlled chamber. Assays with inoculum alone were also used as control samples. Biogas produced from the inoculum were subtracted from the sample assays. The cumulative methane yield (CMY) of FW was calculated by dividing the cumulative volume of methane produced after complete AD by the total mass of VS initially added. All of the batch experiments were performed in triplicate. After methane production stopped, the digestates were finally sampled for determination of total solids (TS), VS, $\mathrm{pH}$, total ammonia nitrogen (TAN), total volatile fatty acids (TVFA) and total inorganic carbon (TIC). All the results were expressed as means \pm standard deviation in this test. 
Table 1

Characteristics of the original and fat-extracted food wastes and inoculum.

\begin{tabular}{|c|c|c|c|c|c|}
\hline Parameter & $\begin{array}{l}\text { Original FW } \\
\text { China (this study) }\end{array}$ & CF extracted FW & Inoculum & $\begin{array}{l}\text { Banks and Zhang (2010) } \\
\text { FW in England }\end{array}$ & $\begin{array}{l}\text { Qiang et al. (2012) } \\
\text { FW in Japan }\end{array}$ \\
\hline TS (\%FM) & $22.1(0.37)$ & $38.5(2.7)$ & $2.23(0.42)$ & $23.7(0.08)$ & $14.3(1.75)$ \\
\hline VS (\%FM) & $20.4(0.12)$ & $34.7(1.8)$ & $1.56(0.19)$ & $21.7(0.09)$ & $13.1(1.71)$ \\
\hline VS/TS (\%) & $92.2(0.51)$ & $90.1(2.2)$ & $79.14(4.23)$ & $91.4(0.39)$ & $91.6(2.84)$ \\
\hline $\mathrm{pH}$ & $5.92(0.12)$ & $5.32(0.06)$ & $7.36(0.06)$ & $4.71(0.01)$ & - \\
\hline TCOD $(\mathrm{g} / \mathrm{L})$ & $251.0(22.4)$ & $314.0(18.9)$ & $2.2(0.1)$ & - & $188(6.53)$ \\
\hline Crude fat (\%TS) & $31.8(1.7)$ & $10.4(1.1)$ & - & $13.8(0.1)$ & - \\
\hline Cellulose (\%TS) & $4.70(0.3)$ & $4.62(0.4)$ & - & $4.61(0.1)$ & - \\
\hline Hemi-cellulose (\%TS) & $10.05(0.9)$ & $9.77(0.6)$ & - & $3.48(0.3)$ & - \\
\hline lignin (\%TS) & $2.12(0.2)$ & $2.31(0.3)$ & - & $1.51(0.0)$ & - \\
\hline TKN (\%TS) & $2.48(0.3)$ & $2.29(0.4)$ & - & $3.42(0.0)$ & - \\
\hline Crude protein (\%TS) & $15.5(1.9)$ & $18.2(0.8)$ & - & $21.5(0.3)$ & - \\
\hline Carbohydrate (\%TS) & $41.6(2.6)$ & $52.7(1.9)$ & - & $41.4(1.6)$ & - \\
\hline C (\%TS) & $50.84(0.14)$ & $49.27(0.81)$ & - & - & - \\
\hline H (\%TS) & $7.20(0.09)$ & $6.94(0.11)$ & - & $48.3(1.0)$ & $47.4(0.01)$ \\
\hline $\mathrm{O}$ (\%TS) & $32.03(0.15)$ & $31.27(0.21)$ & - & $5.53(0.63)$ & $6.65(0.28)$ \\
\hline N (\%TS) & $1.80(0.04)$ & $2.31(0.02)$ & - & $34.3(2.5)$ & $43.7(0.28)$ \\
\hline $\mathrm{S}(\% \mathrm{TS})$ & $0.24(0.02)$ & $0.31(0.04)$ & - & $3.42(0.04)$ & $1.90(0.09)$ \\
\hline $\mathrm{C} / \mathrm{N}$ & 28.2 & 21.3 & - & $0.15(0.01)$ & $0.41(0.06)$ \\
\hline
\end{tabular}

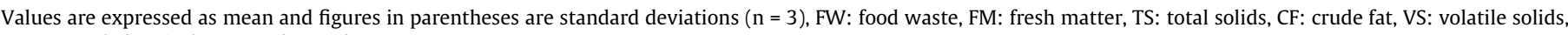
TCOD: total chemical oxygen demand.

\subsection{Analytical methods and calculation}

TS, VS, total chemical oxygen demand (TCOD), total Kjeldahl nitrogen (TKN) and TAN were determined in accordance with the standard methods (APHA, 2005). pH was determined using a digital pH meter (FE20, METTLER TOLEDO, Switzerland). The TIC and TVFA or VOA (volatile organic acids) content were analyzed by titration with $0.05 \mathrm{M} \mathrm{H}_{2} \mathrm{SO}_{4}$ to endpoints of $\mathrm{pH} 5.0$ and 4.4 (Rieger and Weiland, 2006). The crude fat content in FW was measured using soxhlet extraction method (Neves et al., 2009). Crude proteins were calculated by multiplying the TKN by the factor 6.25 (Gelegenis et al., 2007). Oven-dried FW was also used for elemental analysis $(\mathrm{C}, \mathrm{H}, \mathrm{N}, \mathrm{S})$ by an elemental analyzer (Vario EL/ micro cube, Germany). The contents of cellulose, hemicelluloses and lignin were measured using an automatic cellulose analyzer (A200i, ANKOM, America).

The volume of daily biogas production was determined by displacing saturated sodium chloride solution (Zhang et al., 2014). The measured biogas volumes were adjusted to the volumes at standard temperature $\left(0^{\circ} \mathrm{C}\right)$ and pressure $(101.325 \mathrm{kPa})$. Biogas composition was analyzed by gas chromatography (GC-2010 plus, SHIMADZU, Japan) according to the methods described by Zhang et al. (2014).

The CF content in substrate was calculated using Eq. (1) as following:

$\mathrm{CF}(\%)=\frac{M_{\text {fat-extracted FW }} \times C F_{\text {fat-extracted FW } \%+M_{\text {extracted } \mathrm{CF}}}}{M_{C F \text {-extracted FW }}+M_{\text {extracted } \mathrm{CF}}} \times 100 \%$

where $\mathrm{M}_{\text {fat-extracted FW }}$ means the mass of fat free $\mathrm{FW}, \mathrm{CF}_{\text {fat-extracted }}$ Fw\% means the percent of crude fat in fat-extracted FW, $\mathrm{M}_{\text {extracted }}$ CF means the mass of crude fat added in the fat-extracted FW.

Theoretical methane potential (TMP) of FW with different CF contents was calculated based on the stoichiometric conversion of organic matter according to Bruni et al. (2010):

TMP $(\mathrm{mL} / \mathrm{gVS})=0.415$ carbohydrates $(\% \mathrm{TS})$

$$
\begin{aligned}
& +0.496 \text { proteins (\%TS) } \\
& +1.014 \text { fats }(\% \mathrm{TS})
\end{aligned}
$$

In addition, on the basis of the elemental composition of original FW (C, H, O, N, S - Table 1), the theoretical biogas yield and composition original FW can be evaluated according to Boyl's formula (Eq. (3)), which is derived by stoichiometric conversion of the compound to $\mathrm{CH}_{4}, \mathrm{CO}_{2}, \mathrm{NH}_{3}$ and $\mathrm{H}_{2} \mathrm{~S}$ (Achinas and Euverink, 2016).

$$
\begin{aligned}
\mathrm{C}_{\mathrm{n}} \mathrm{H}_{\mathrm{a}} \mathrm{O}_{\mathrm{b}} \mathrm{N}_{\mathrm{c}} \mathrm{S}_{\mathrm{d}}+\left[\mathrm{n}-\frac{\mathrm{a}}{4}-\frac{\mathrm{b}}{2}+\frac{3 \mathrm{c}}{4}+\frac{\mathrm{d}}{2}\right] \mathrm{H}_{2} \mathrm{O} \\
\rightarrow \\
\rightarrow\left[\frac{\mathrm{n}}{2}-\frac{\mathrm{a}}{8}+\frac{\mathrm{b}}{4}+\frac{3 \mathrm{c}}{8}+\frac{\mathrm{d}}{4}\right] \mathrm{CO}_{2}+\left[\frac{\mathrm{n}}{2}+\frac{\mathrm{a}}{8}-\frac{\mathrm{b}}{4}-\frac{3 \mathrm{c}}{8}-\frac{\mathrm{d}}{4}\right] \mathrm{CH}_{4} \\
\quad+\mathrm{CNH}_{3}+\mathrm{dH}_{2} \mathrm{~S}
\end{aligned}
$$

The VS removal rate was calculated based on total mass removal from the testing reactors and the blank reactors following the method of Kafle et al. (2013).

VS removal $(\%)=\frac{(F+I) \times a-I \times b}{F} \times 100$

where $F=$ total $\mathrm{VS}_{\text {feed }}$ added to reactor $(\mathrm{g}) ; I=$ total $\mathrm{VS}_{\text {inoculum }}$ added to reactor $(\mathrm{g}) ; a=$ calculated VS removal of feed plus inoculum based on total initial and final mass of VS present in the reactor (\%); $b=$ calculated VS removal of inoculum in blank reactor (\%).

\subsection{Kinetic model}

Some insights into the potential behavior of the materials in a full-scale system can be provided effectively by kinetics analysis. In order to explain the combined effects of $\mathrm{CF}$ and fermentation concentration on methane production of FW, the hydrolysis kinetic constant $(K)$, the maximum methane production rate $\left(R_{\max }\right)$, and the lag phase $(\lambda)$ during AD process was investigated by kinetics models. First-order kinetics model has been used to describe the process of methane production of some organic materials (manure, agricultural wastes, and food waste et al.) (Kafle et al., 2014, 2013; Kafle and Sang, 2013; Rincón et al., 2010). The cumulative methane production was predicted in this batch experiment based on Eq. (5).

Apart from the methane yield, the duration of the lag phase $(\lambda)$ is also an important factor used to determine the efficiency of AD. $\lambda$ can be calculated using the modified Gompertz model which is a typical "S" style curve equation (Eq. (6)).

$M(t)=M_{\max } \times 1-\left(\mathrm{e}^{-K t}\right)$ 
$M(t)=M_{\max } \exp \left\{-\exp \left[\frac{R_{\max } \mathrm{e}}{M_{\max }}(\lambda-t)+1\right]\right\}$

where $M(t)$ is the cumulative methane production at time $t(\mathrm{~mL} /$ gVS); $M_{\max }$ was the potential maximum methane yield (mL/gVS); $K$ is methane production rate constant (first-order hydrolysis kinetic constant, $\left.\mathrm{d}^{-1}\right) ; R_{\max }$ is the maximum methane production rate ( $\mathrm{mL} / \mathrm{gVS}-\mathrm{d}) ; \lambda$ is the lag phase (d); $\mathrm{t}$ is the duration of the assay (d) and e is the $\exp (1)=2.7183$.
A nonlinear least-square regression analysis was performed using SigmaPlot 12.0 software and Matlab R2004 (Versions: 7.0.0.19920) software for determining $K, \lambda, R_{\max }, M_{\max }$, and $R^{2}$.

\subsection{Statistical analysis}

Differences in the methane yields among results obtained of different CF contents of FW samples at four substrate concentrations were evaluated by using single factor analysis of variances
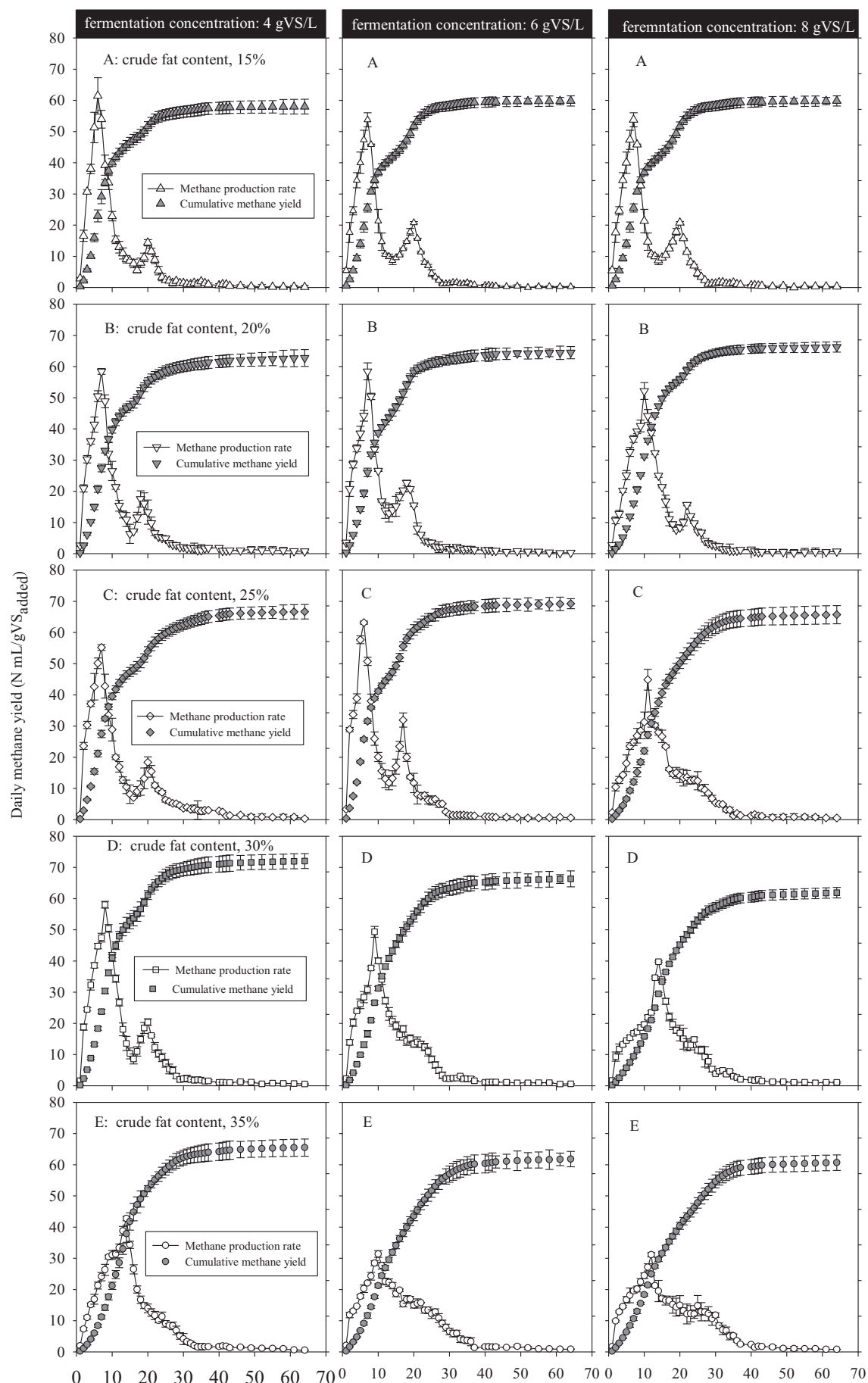
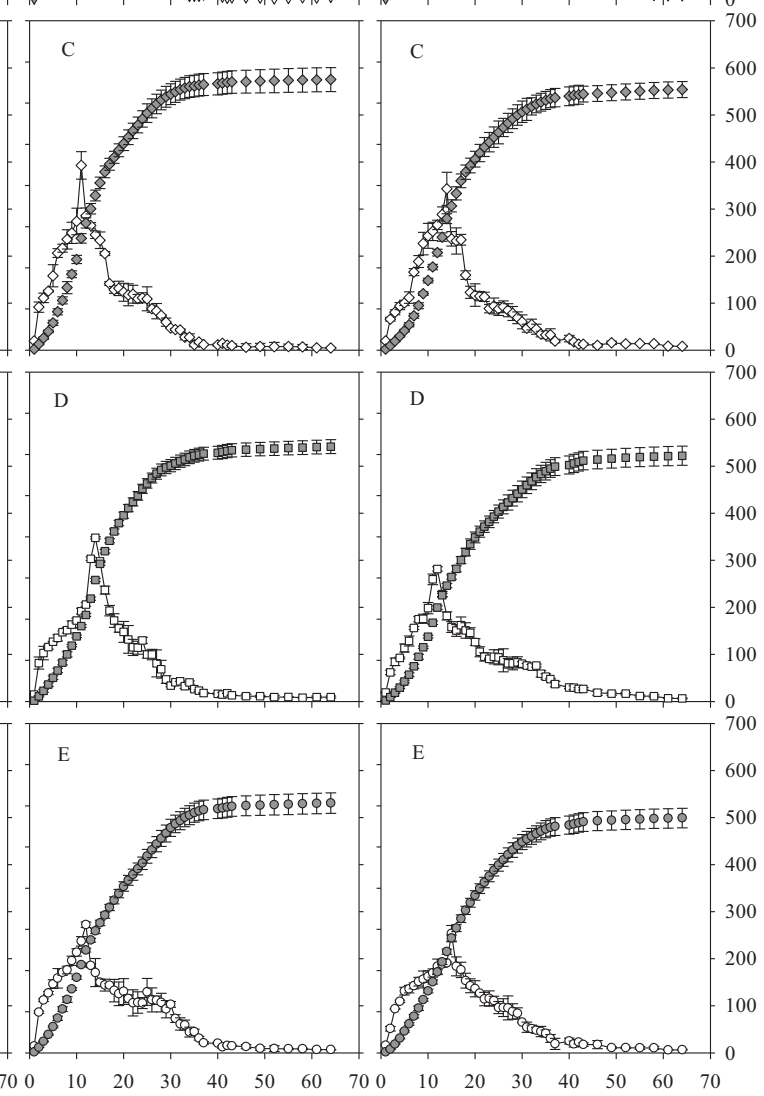

Time (days)
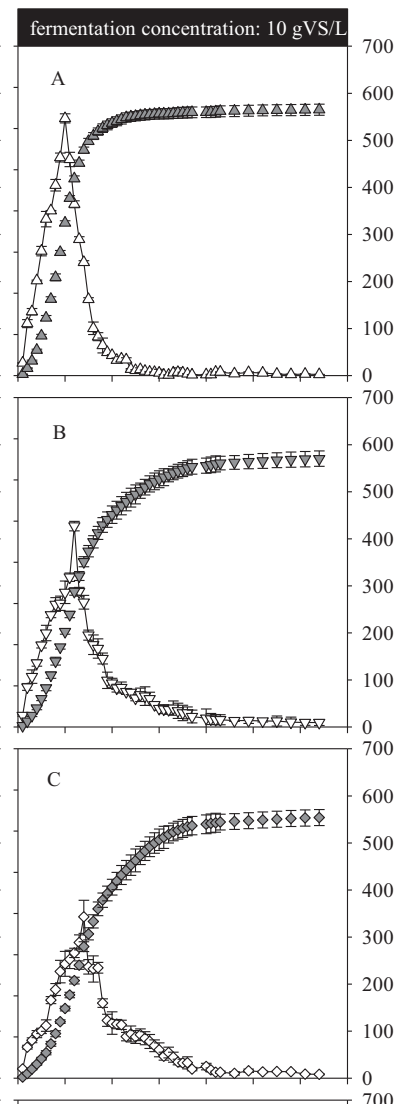

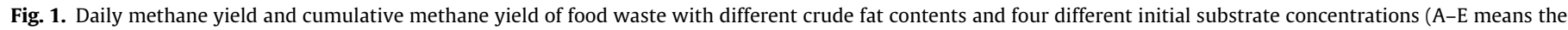
different crude fat contents. A: 15\%TS, B: 20\%TS, C: 25\%TS, D: 30\%TS, E: 35\%TS; 4-10 gVS/L means the initial fermentation concentrations). 


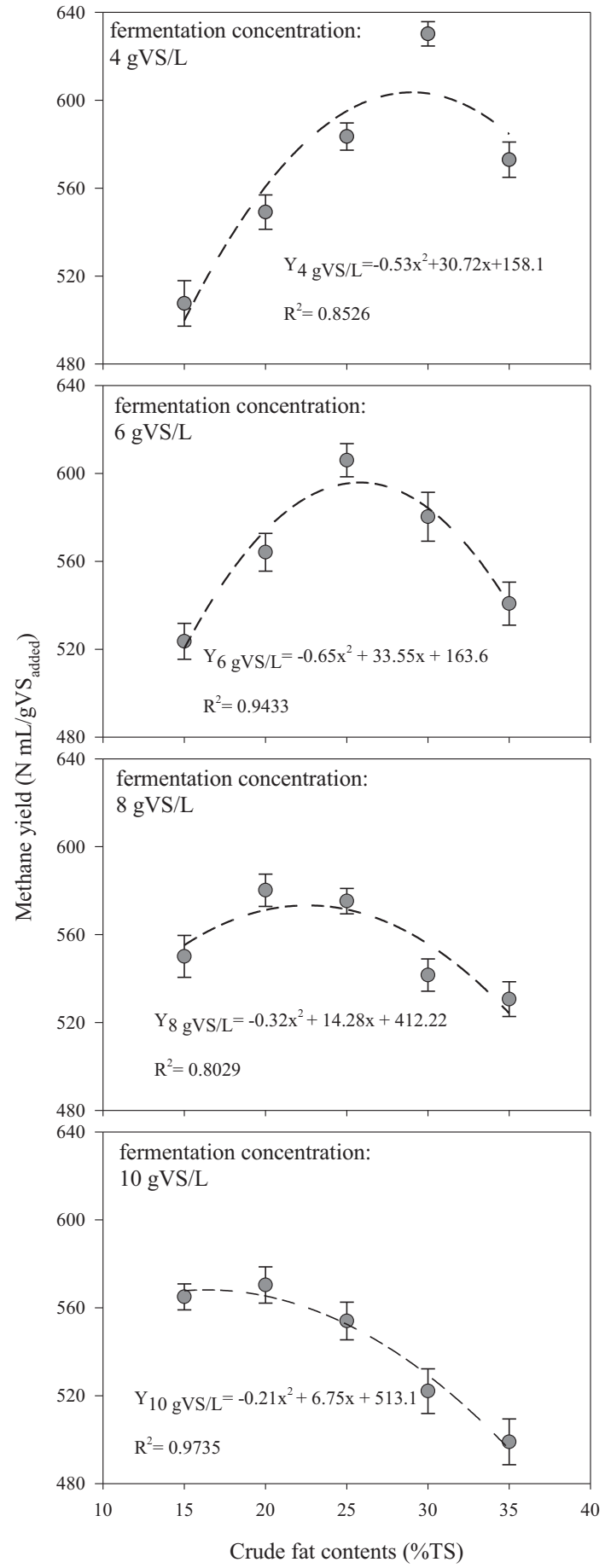

Fig. 2. Effect of crude fat content on the cumulative methane yield from food waste at different initial substrate concentrations.
(ANOVA) in Excel software 2007. Statistical significance was established at a $P$-value less than 0.05 level (Kafle et al., 2013).

\section{Results and discussion}

\subsection{Daily methane yield from FW depending on CF content and substrate concentration}

The daily methane yield (DMY) and cumulative methane yield (CMY) of FW with different CF contents at four initial substrate concentrations are shown in Fig. 1.

With low CF contents (15\%, 20\%, and 25\%) and low initial substrate concentrations, two peaks in the DMY were found. The maximum DMY of FW with CF contents of $15 \%, 20 \%$, and $25 \%$ at $4 \mathrm{gVS} / \mathrm{L}$ were 61.5 (d 6), 58.4 (d 7), and 55.2 (d 7) $\mathrm{mL} \mathrm{CH}_{4} / \mathrm{gVS}$-d, respectively, and the values at $6 \mathrm{gVS} / \mathrm{L}$ were 53.8 (d 7), 58.5 (d 7), and 63.2 (d 6) $\mathrm{mL} \mathrm{CH}_{4} / \mathrm{gVS}-\mathrm{d}$, respectively. Similarly, Kafle et al (2013) also found two peaks for the daily biogas production rate during the $\mathrm{AD}$ of fish waste at a low fermentation concentration ( $2.5 \mathrm{gVS} / \mathrm{L})$. The two DMY peaks could be due to the high concentration of carbohydrates (41.6\%) in FW, which were biodegraded rapidly and then contributed to the first peak (around day 6). Kafle and Kim (2013) pointed out that the conversion of carbohydrates can be faster than the conversion of proteins and fats. Thus, the second DMY peak (around day 18) may be attributed to the subsequent degradation of crude protein and CF. However, when the CF content increased to $35 \%$, only one daily methane production peak was found for $4 \mathrm{gVS} / \mathrm{L}$ and $6 \mathrm{gVS} / \mathrm{L}$, at $14 \mathrm{~d}\left(42.7 \mathrm{~mL} \mathrm{CH}_{4} /\right.$ gVS-d) and $10 \mathrm{~d}$, respectively. In addition, at a substrate concentration of $8 \mathrm{gVS} / \mathrm{L}$, two daily methane production peaks were clearly observed only with the lowest CF content. When the substrate concentration was increased gradually to $10 \mathrm{gVS} / \mathrm{L}$, only one daily methane production peak was found, at $10 \mathrm{~d}, 12 \mathrm{~d}, 14 \mathrm{~d}, 12 \mathrm{~d}$, and $15 \mathrm{~d}$ for CF contents of $15 \%, 20 \%, 25 \%, 30 \%$, and $35 \%$, respectively. One reason for the presence of only one DMY peak at high substrate concentrations could be the accumulation of LCFAs with the hydrolysis of CF (Khanal, 2008). LCFAs or fat could accumulate on the surface of the microbes and thus inhibit transport processes and hinder the rapid degradation of carbohydrates (Noutsopoulos et al., 2013). In this way, the degradation of carbohydrates would be delayed and integrated with the conversion of proteins and fats, resulting in only one DMY peak occurring under conditions of a high initial substrate concentration and CF content.

\subsection{Cumulative methane yield (CMY) from FW depending on $C F$ content and substrate concentration}

According to the stoichiometric conversion formula, the calculated theoretical methane potentials (TMP) of original FW is $599.9 \mathrm{~mL} / \mathrm{gVS}$, and the TMPs of FW with CF contents of $15 \%, 20 \%$, $25 \%, 30 \%$, and $35 \%$ are $512.3,568.6,624.9,681.3$, and $737.6 \mathrm{~mL} /$ gVS, respectively. As shown in Fig. 1 and Table 2, the CMYs of FW at $4 \mathrm{gVS} / \mathrm{L}$ with $\mathrm{CF}$ contents of $15 \%, 20 \%, 25 \%, 30 \%$, and $35 \%$

Table 2

Methane yield of food waste with different crude fat contents under four initial substrate concentrations.

\begin{tabular}{|c|c|c|c|c|}
\hline \multirow[t]{2}{*}{ Crude fat contents (\%) } & \multicolumn{4}{|c|}{ Measured methane yield $\left(\mathrm{mL} / \mathrm{gVS}_{\text {added }}\right)$} \\
\hline & $4 \mathrm{gVS} / \mathrm{L}$ & $6 \mathrm{gVS} / \mathrm{L}$ & $8 \mathrm{gVS} / \mathrm{L}$ & $10 \mathrm{gVS} / \mathrm{L}$ \\
\hline 15 & $507.6(14.7)^{\mathrm{a} ; \mathrm{A}}$ & $523.6(14.3)^{\mathrm{a}, \mathrm{b} ; \mathrm{A}}$ & $550.1(19.1)^{\mathrm{a} ; \mathrm{A}}$ & $565.0(11.8)^{\mathrm{a} ; \mathrm{A}}$ \\
\hline 20 & $549.1(16.6)^{\mathrm{a}, \mathrm{b} ; \mathrm{A}}$ & $564.2(17.2)^{\mathrm{a} ; \mathrm{A}}$ & $580.2(14.6)^{\mathrm{a} ; \mathrm{A}}$ & $570.4(16.5)^{\mathrm{a}, \mathrm{b} ; \mathrm{A}}$ \\
\hline 25 & $583.5(14.3)^{\mathrm{a}, \mathrm{b} ; \mathrm{A}, \mathrm{B}}$ & $606.0(19.1)^{\mathrm{a} ; \mathrm{A}}$ & $575.2(25.6)^{\mathrm{a}, \mathrm{b} ; \mathrm{A}, \mathrm{B}}$ & $554.0(17.1)^{\mathrm{b}, \mathrm{c} ; \mathrm{B}}$ \\
\hline 30 & $630.2(18.1)^{\mathrm{b} ; \mathrm{A}}$ & $580.3(22.5)^{\mathrm{a}, \mathrm{b} ; \mathrm{A}, \mathrm{B}}$ & $541.6(13.8)^{\mathrm{b} ; \mathrm{B}, \mathrm{C}}$ & $522.1(20.3)^{\mathrm{b}, \mathrm{c} ; \mathrm{C}}$ \\
\hline 35 & $573.0(16.9)^{\mathrm{a}, \mathrm{b} ; \mathrm{A}}$ & $540.8(18.7)^{\mathrm{b} ; \mathrm{A}, \mathrm{B}}$ & $530.6(20.4)^{\mathrm{b} ; \mathrm{A}, \mathrm{B}}$ & $499.0(18.2)^{\mathrm{c} ; \mathrm{B}}$ \\
\hline
\end{tabular}

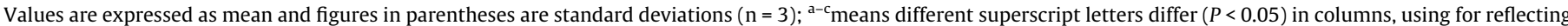

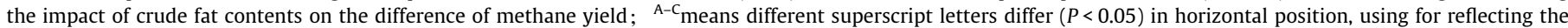
impact of initial fermentation concentrations on the difference of methane yield. 
were $507.6,549.1,583.5,630.2$, and $573.0 \mathrm{~mL} / \mathrm{gVS}_{\text {added, }}$, respectively. As expected, the CMY was improved by $24.2 \%$ as the CF content increased from $15 \%$ to $30 \%$, confirming that CF had a higher methane production potential than proteins and carbohydrates (Bernat et al., 2008; Kafle and Kim, 2013; Sompong et al., 2012). Similarly, Bernat et al. (2008) also reported that in the cofermentation of sewage sludge and oil waste, biogas production increased with increasing content of oil waste. Conversely, as the CF content increased to $35 \%$, the CMY decreased by $9.1 \%$ compared to that with $30 \% \mathrm{CF}$. One possible reason for the lower CMY with a higher CF content could be that the high concentration of LCFAs produced by hydrolysing $\mathrm{CF}$ inhibit the degradation process (Cho et al., 2013). Nevertheless, no significant difference was observed in the CMY values when using CF contents of $20 \%, 25 \%$, and $35 \%$ at a $95 \%$ confidence interval $(P>0.05)$. The results also indicated that the CMY did not increase linearly with respect to an increase in the $\mathrm{CF}$ content at $4 \mathrm{gVS} / \mathrm{L}$, and the nonlinear functional relationship between the CMY and $\mathrm{CF}$ contents at $4 \mathrm{gVS} / \mathrm{L}$ was $\mathrm{Y}_{4 \mathrm{gVS} / \mathrm{L}}=-0.53 \mathrm{X}_{\mathrm{CF}}^{2}+30.7 \mathrm{X}_{\mathrm{CF}}+158.1\left(\mathrm{R}^{2}=0.853\right)($ Fig. 2). Similarly, at fermentation concentrations of 6,8 , and $10 \mathrm{gVS} / \mathrm{L}$, the functional relationship between the CMY and CF contents also was not linear but followed a bell curve, which was $\mathrm{Y}_{6 \mathrm{gVS} / \mathrm{L}}=$ $-0.65 \mathrm{X}_{\mathrm{CF}}^{2}+33.6 \mathrm{X}_{\mathrm{CF}}+163.6\left(\mathrm{R}^{2}=0.943\right), \mathrm{Y}_{8 \mathrm{gVS} / \mathrm{L}}=-0.32 \mathrm{X}_{\mathrm{CF}}^{2}+14.3 \mathrm{X}_{\mathrm{CF}}+$ $412.2 \quad\left(R^{2}=0.803\right)$, and $\mathrm{Y}_{10 \mathrm{gVS} / \mathrm{L}}=-0.21 \mathrm{X}_{\mathrm{CF}}^{2}+6.8 \mathrm{X}_{\mathrm{CF}}+513.1$ $\left(R^{2}=0.974\right)$, respectively. Based on the bell curve, maximum CMYs at substrate concentrations of $4,6,8$, and $10 \mathrm{gVS} / \mathrm{L}$ were achieved with different CF contents, which was $30 \%\left(630.2 \mathrm{~mL} / \mathrm{gVS}_{\text {added }}\right)$, $25 \% \quad\left(606.0 \mathrm{~mL} / \mathrm{gVS}_{\text {added }}\right), 20 \% \quad\left(580.2 \mathrm{~mL} / \mathrm{gVS}_{\text {added }}\right)$, and $20 \%$ $\left(570.4 \mathrm{~mL} / \mathrm{gVS}_{\text {added }}\right)$, respectively. These fitted curves suggested that for a full-scale FW biogas plant, the CF should be adjusted based on the FW output. Moreover, the bell curve indicated a significant inhibition of methane production at 8 and $10 \mathrm{gVS} / \mathrm{L}$ with $\mathrm{CF}$ contents of $30 \%$ and $35 \%$ due to the higher concentration of $\mathrm{CF}$ in FW. The hydrolysis of CF was shown to result in more adsorption of LCFAs onto the surface of the microbes, inhibiting the biochemical conversion of the substrates (Cho et al., 2013). Moreover, the ANOVA results indicated that the lowest CMY achieved at $8 \mathrm{gVS} /$ $\mathrm{L}\left(530.6 \mathrm{~mL} / \mathrm{gVS}_{\text {added }}\right)$ and $10 \mathrm{gVS} / \mathrm{L}\left(499.0 \mathrm{~mL} / \mathrm{gVS}_{\text {added }}\right)$ was significantly lower than the maximum CMY $(P<0.05)$. This nonlinear phenomenon corresponded with the findings from Cho et al. (2013), who reported that changing the LCFA concentrations from 0.5 to 2.0 gCOD-LCFAs/L increased the methane yield, but a significant decrease was observed at 3.0 gCOD-LCFAs/L. Together, the results from the present study and previous studies indicate that methane production is influenced by a synergistic effect between substrate concentration and CF content.

From another aspect, the output of FW changes seasonally, which results in load fluctuations in field-scale biogas plants. Thus, the functional relationship between methane yield and substrate concentration at a constant CF content was also evaluated in this study (Fig. 3). As shown in Table 2 and Fig. 3, at a CF of $15 \%$, the CMY increased gradually as the substrate concentration increased from $4 \mathrm{gVS} / \mathrm{L}$ to $10 \mathrm{gVS} / \mathrm{L}$, and the linear relationship was $\mathrm{Y}_{15 \%}$ $=9.94 \mathrm{X}_{\text {load }}+467.0\left(\mathrm{R}^{2}=0.988\right)$. No significant differences were observed in the CMY $(P>0.05)$ at a $15 \%$ CF content under different substrate concentrations conditions. This indicates that for fieldscale biogas plants treating FW, the load can be adjusted appropriately when the CF content of the collected FW is low. Bernat et al. (2008) also reported that with an appropriate oil content, the daily biogas yield increased from 0.79 to $1.98 \mathrm{~L} / \mathrm{L}$ as the fermentation concentration changed from 0.9 to $3.1 \mathrm{gVS} / \mathrm{L} / \mathrm{d}$. On the contrary, as the substrate concentration increased, the CMY showed an obvious downtrend with $30 \%$ and $35 \%$ CF contents. The association of a low methane yield at a high initial substrate concentration with a high $\mathrm{CF}$ content indicated that the substrate had the potential to inhibit to the AD process when overloaded. Similarly, Sompong

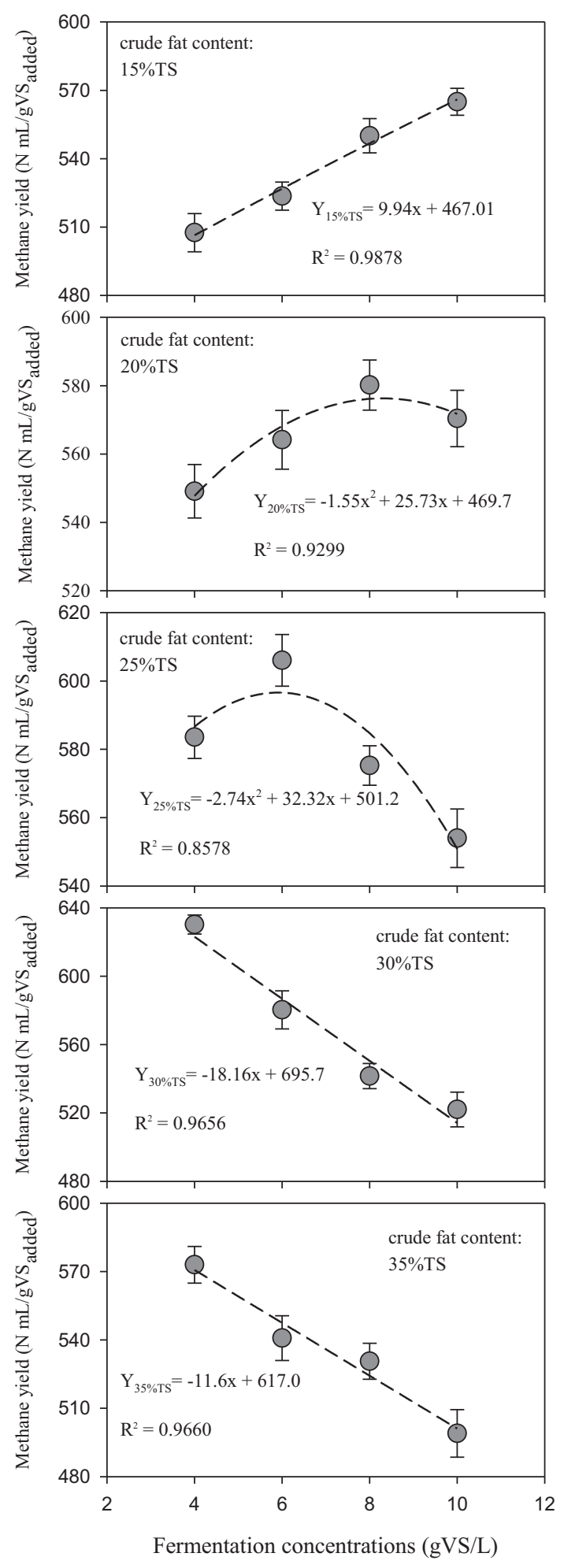

Fig. 3. Effect of substrate concentration on the cumulative methane yield from food waste with different crude fat contents.

et al. (2012) pointed out that methane production from oil-rich palm oil mill effluent decreased by $24.9 \%$ as the substrate concentration increased from $13 \mathrm{gVS} / \mathrm{L}$ to $39 \mathrm{gVS} / \mathrm{L}$. However, at a constant CF content of $25 \%$, increasing the substrate concentration caused the methane yield to first increase and then decrease (a bell curve). With a $25 \% \mathrm{CF}$ content, the maximum CMY $(606.9 \mathrm{~mL} /$ $\mathrm{gVS}_{\text {added }}$ ) was obtained at $6 \mathrm{gVS} / \mathrm{L}$, and this value is significantly 
Table 3

Final characteristics of the digestates of food waste with different crude fat contents.

\begin{tabular}{|c|c|c|c|c|c|c|c|}
\hline Crude fat contents (\%) & Substrate concentration (gVS/L) & $\mathrm{pH}$ & TAN (mg/L) & $\mathrm{TIC}(\mathrm{mg} \mathrm{CaCO} / \mathrm{L})$ & TVFA (mg CH$\left.{ }_{3} \mathrm{COOH} / \mathrm{L}\right)$ & TVFA/TIC & $\mathrm{VS}_{\text {removal }}(\%)$ \\
\hline \multirow[t]{4}{*}{15} & 4 & $7.25(0.04)$ & $614.9(22.5)$ & $5550(146)$ & $753(48)$ & 0.14 & $89.2(2.3)$ \\
\hline & 6 & $7.18(0.07)$ & $899.2(33.8)$ & $7200(353)$ & $916(77)$ & 0.13 & $88.9(3.4)$ \\
\hline & 8 & $7.22(0.11)$ & $1083.4(21.7)$ & 8600 (353) & $1407(95)$ & 0.16 & $89.3(3.7)$ \\
\hline & 10 & $7.27(0.02)$ & $1645.1(34.2)$ & $7700(406)$ & $1749(108)$ & 0.23 & $91.0(4.1)$ \\
\hline \multirow[t]{4}{*}{20} & 4 & $7.13(0.03)$ & $575.0(17.3)$ & 4850 (133) & $1080(38)$ & 0.22 & $90.5(3.0)$ \\
\hline & 6 & $7.19(0.12)$ & $1047.7(33.0)$ & $7850(424)$ & $1250(125)$ & 0.16 & $91.4(2.8)$ \\
\hline & 8 & $7.26(0.08)$ & $1199.0(32.9)$ & $8400(459)$ & $1430(210)$ & 0.17 & $91.6(3.1)$ \\
\hline & 10 & $7.21(0.12)$ & $1487.5(24.8)$ & 8250 (830) & $1890(205)$ & 0.23 & $90.4(1.8)$ \\
\hline \multirow[t]{4}{*}{25} & 4 & $7.23(0.14)$ & $548.5(17.1)$ & 4550 (113) & 1065(49) & 0.23 & $88.7(1.4)$ \\
\hline & 6 & $7.18(0.07)$ & $805.9(26.4)$ & 7050 (194) & $948(77)$ & 0.13 & $90.6(1.7)$ \\
\hline & 8 & $7.17(0.12)$ & $1254.0(30.1)$ & $8750(353)$ & $1661(218)$ & 0.19 & $87.6(4.3)$ \\
\hline & 10 & $7.06(0.08)$ & $1500.8(22.3)$ & 7050 (406) & 2855(106) & 0.40 & $80.7(3.3)$ \\
\hline \multirow[t]{4}{*}{30} & 4 & $7.09(0.08)$ & $525.0(22.0)$ & 4700 (169) & $589(76)$ & 0.13 & $91.8(1.4)$ \\
\hline & 6 & $7.22(0.04)$ & $821.5(30.2)$ & $6900(424)$ & $1347(152)$ & 0.20 & $86.2(4.1)$ \\
\hline & 8 & $7.02(0.09)$ & $1234.4(31.7)$ & $7250(370)$ & 2501(176) & 0.34 & $76.1(5.1)$ \\
\hline & 10 & $6.78(0.11)$ & $1400.9(33.5)$ & 6475 (167) & $3833(216)$ & 0.53 & $70.2(2.9)$ \\
\hline \multirow[t]{4}{*}{35} & 4 & $7.13(0.15)$ & $476.9(21.5)$ & $4500(135)$ & $1870(80)$ & 0.28 & $83.6(5.2)$ \\
\hline & 6 & $7.02(0.01)$ & 799.3(26.9) & $7500(187)$ & $3150(112)$ & 0.42 & $77.4(3.9)$ \\
\hline & 8 & $6.67(0.13)$ & $1178.9(18.7)$ & $7200(205)$ & $4720(160)$ & 0.66 & 68.1(3.5) \\
\hline & 10 & $6.38(0.02)$ & $1507.5(23.8)$ & $6550(148)$ & $5380(270)$ & 0.82 & $62.8(3.7)$ \\
\hline
\end{tabular}

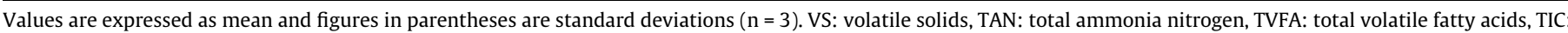
total inorganic carbon.

Table 4

Kinetics results of food waste with different crude fat contents obtained from the first-order kinetic model.

\begin{tabular}{|c|c|c|c|c|c|c|}
\hline \multirow[t]{2}{*}{ Crude fat content (\%) } & \multirow[t]{2}{*}{ Fermentation concentration (gVS/L) } & \multirow[t]{2}{*}{$R^{2}$} & \multirow[t]{2}{*}{$K\left(\mathrm{~d}^{-1}\right)$} & \multicolumn{3}{|c|}{ Cumulative methane yield (64 days) } \\
\hline & & & & PM (mL/gVS) & $\mathrm{MM}(\mathrm{mL} / \mathrm{gVS})$ & $\mathrm{DM}(\%)$ \\
\hline \multirow[t]{4}{*}{15} & 4 & 0.9681 & 0.0964 & 520.1 & 507.6 & 2.5 \\
\hline & 6 & 0.9732 & 0.0808 & 547.4 & 523.6 & 4.5 \\
\hline & 8 & 0.9593 & 0.0865 & 575.3 & 550.1 & 4.6 \\
\hline & 10 & 0.9162 & 0.0847 & 597.2 & 565.0 & 5.7 \\
\hline \multirow[t]{4}{*}{20} & 4 & 0.9735 & 0.0861 & 563.8 & 549.1 & 2.7 \\
\hline & 6 & 0.9705 & 0.0809 & 589.2 & 564.2 & 4.4 \\
\hline & 8 & 0.9440 & 0.0667 & 626.7 & 580.2 & 8.0 \\
\hline & 10 & 0.9512 & 0.0539 & 630.4 & 570.4 & 10.5 \\
\hline \multirow[t]{4}{*}{25} & 4 & 0.9819 & 0.0759 & 603.0 & 583.5 & 3.3 \\
\hline & 6 & 0.9796 & 0.0822 & 629.8 & 606.0 & 3.9 \\
\hline & 8 & 0.9504 & 0.0503 & 652.5 & 575.2 & 13.4 \\
\hline & 10 & 0.9408 & 0.0425 & 652.0 & 554.0 & 17.7 \\
\hline \multirow[t]{4}{*}{30} & 4 & 0.9659 & 0.0743 & 664.0 & 630.2 & 5.4 \\
\hline & 6 & 0.9609 & 0.0631 & 627.2 & 580.3 & 8.1 \\
\hline & 8 & 0.9386 & 0.0421 & 642.0 & 541.6 & 18.5 \\
\hline & 10 & 0.9609 & 0.0372 & 631.4 & 522.1 & 20.9 \\
\hline \multirow[t]{4}{*}{35} & 4 & 0.9370 & 0.0513 & 648.4 & 573.0 & 13.2 \\
\hline & 6 & 0.9619 & 0.0451 & 624.6 & 540.8 & 15.5 \\
\hline & 8 & 0.9639 & 0.0399 & 632.6 & 530.6 & 19.2 \\
\hline & 10 & 0.9530 & 0.0374 & 608.4 & 499.0 & 21.9 \\
\hline
\end{tabular}

PM: Predicted methane yield (mL/gVS)-64 days.

MM: Measure methane yield (mL/gVS)-64 days.

DM: Difference between measured and predicted methane yield (\%).

higher than the minimum CMY $\left(554.0 \mathrm{~mL} / \mathrm{gVS}_{\text {added }}\right)$ achieved at $10 \mathrm{gVS} / \mathrm{L}(P<0.05)$ (Table 2$)$. These different methane generation trends under diverse $\mathrm{CF}$ contents suggest that the substrate concentration could be adjusted based on the CF content in the FW to obtain the optimum economic benefits.

\subsection{The final characteristics of the digestates}

After 64 days AD process, the final characteristics of the digestates in this batch experiment were determined in terms of $\mathrm{pH}$, TAN, VFA, TIC, VFA/TIC ratio, and VS removal rate (Table 3 ).

The final $\mathrm{pH}$ values (7.06-7.27) of the digestate from FW with lower CF contents (15\%,20\%, and $25 \%$ ) at four initial substrate con- centrations were all slightly higher than the initial value (7.00), which was suitable for the normal growth of anaerobic microorganisms (Raposo et al., 2009). The appropriate $\mathrm{pH}$ was consistent with the low VFA/TIC ratio (0.13-0.4) and high VS removal rate (80.7\%-91.6\%) under the low CF content conditions. Similarly, Raposo et al. (2009) also reported that stable batch anaerobic digestion operation was observed with a low range of VFA/TIC ratio $(0.30-0.40$ or less). However, a drop in $\mathrm{pH}(<6.80)$ and increase in the VFA/TIC ratio ( $>0.4$ ) was found with CF contents of $30 \%$ (load: $10 \mathrm{gVS} / \mathrm{L}$ ) and 35\% (load: 8 and $10 \mathrm{gVS} / \mathrm{L}$ ), which further inhibited methane fermentation and resulted in a lower VS removal rate (62.8\%-70.2\%). As has been reported, a VFA/TIC ratio higher than $0.3-0.4$ would cause the operation of the anaerobic digestion pro- 
cess to be unstable (Borja et al., 2004). The total ammonia (TAN) level also should be considered during the $\mathrm{AD}$ of FW because of the high concentration of crude proteins (Banks et al., 2012). In this study, TAN concentrations fell in the range of $476.9-1645.1 \mathrm{mg} / \mathrm{L}$, which was significantly lower than the reported critical concentration (3000 mg/L) (Karthikeyan and Visvanathan, 2012). This indicated that TAN was not a key inhibiting factor of the AD of FW in this study. These results did not correspond with the findings of Banks et al. (2012), who reported an ammonia concentration above $5000 \mathrm{mg} / \mathrm{L}$ during semi-continuous AD. The different TAN levels could be caused by the different crude protein contents in the two types of FW. Regarding the VS removal rate, Table 3 clearly shows that the VS removal rate decreased from around $90 \%$ to below $70 \%$ as the CF content increased from $15 \%$ to $35 \%$, especially at a high substrate concentration of $10 \mathrm{gVS} / \mathrm{L}$.

\subsection{Kinetic model study results}

The parameters $K, \lambda, R_{\max }, M_{\max }$ and $R^{2}$ derived from the firstorder kinetic model and the modified Gompertz model are shown in Tables 4 and 5.

As shown in Table 4, the methane production rate constant $(K)$ values were similar among the four different initial substrate concentrations with a CF content of $15 \%\left(0.0808-0.0964 \mathrm{~d}^{-1}\right)$, but these $K$ values were higher than those obtained at a 35\%TS CF content (0.0374-0.0513 $\mathrm{d}^{-1}$ ). However, Kafle et al. (2013) reported a lower $K$ value for pacific saury fish waste (PSFW, $0.033 \mathrm{~d}^{-1}$ ), mackerel fish waste (MFW, $0.020 \mathrm{~d}^{-1}$ ) and cuttle fish waste (CFW, $0.017 \mathrm{~d}^{-1}$ ) with the CF contents of $36.4 \% 49.5 \%$, and $46.7 \%$, respectively. With CF contents of $20 \%, 25 \%$, and $30 \%$, the trend was similar, that is, the $K$ values at lower substrate concentrations (4.0 and $6.0 \mathrm{gVS} / \mathrm{L}$ ) were higher than those at higher substrate concentrations ( 8.0 and $10.0 \mathrm{gVS} / \mathrm{L}$ ).

As shown in Table 5 , the maximum methane production rate $\left(R_{\max }\right)$ estimated by the modified Gompertz model showed a similar trend as found for the cumulative methane production. The maximum $R_{\max }$ values for CF contents of $15 \%, 20 \%, 25 \%, 30 \%$, and
$35 \%$ were obtained at initial AD concentrations of $10,8,6,4$, and $4 \mathrm{gVS} / \mathrm{L}$, which was $55.1,40.0,36.0,40.1$, and $34.2 \mathrm{~mL} / \mathrm{gVS}-\mathrm{d}$, respectively. This result corresponded with the finding from Cho et al. (2013), who reported that the $R_{\max }$ values for FW and lipidfree FW were 55.1 and $45.0 \mathrm{~mL} / \mathrm{gVS}$-d, respectively (Cho et al., 2013). With a higher load, the $R_{\max }$ decreased gradually as the CF content increased from $15 \%$ to $35 \%$. Compared with the results in this study, the $R_{\max }$ values for PSFW $(22.8 \mathrm{~mL} / \mathrm{gVS}-\mathrm{d})$, MFW (19.6 mL/gVS-d), and CFW (16.1 mL/gVS-d) was reported by Kafle et al. (2013) were relatively lower. The reason for low $K$ and $R_{\max }$ values with a high CF content and load could be the inhibition by LCFAs as discussed above.

In addition to the $K$ and $R_{\max }$, the $\lambda$ and digestion time were also analyzed to evaluate the substrate biodegradability and utilization rate. The technical digestion time $\left(T_{90}\right)$ is defined as the time needed to obtain a $90 \%$ yield of cumulative methane, and the effective methane production period $\left(T_{e f}\right)$ was calculated by subtracting $\lambda$ from $T_{90}$ (Table 5) (Kafle and Sang, 2013). The lag-time $(\lambda)$ increased as both the CF contents in FW and substrate concentrations increased. As shown in Table 5, with the CF content and initial substrate concentration of $35 \%$ and $10 \mathrm{gVS} / \mathrm{L}, \lambda$ increased from 0.4-1.1 to 7.1 days. One reason for the longer lag phase is the slow degradation of fats, and another reason may be due to inhibition by LCFAs produced via the $\beta$-oxidation pathway (Kafle and Kim, 2013). However, the maximum $\lambda$ (7.1 days) in this study was slightly lower than the $\lambda$ achieved by Cho et al. (2013), who reported that the $\lambda$ increased to 20 days with 3.0 gCOD-LCFAs/L. At the lowest CF content (15\%), a relatively lower $T_{90}$ (16-22 days) and $T_{e f}$ (12.1-21.1 days) values were obtained. However, the $T_{90}$ and $T_{e f}$ obtained with CF contents of $20-35 \%$ were not significantly different. As the CF content was gradually increased to $35 \%$, the $T_{90}$ and $T_{\text {ef }}$ increased to $26-31$ days and $22.6-25.0$ days, respectively. Zhang et al. (2014) pointed out a $90 \%$ methane production duration can be considered as the hydraulic retention time (HRT) for a largescale continuous biogas plant. Hence, according to the lag-time $(\lambda)$ calculated by the modified Gompertz model, the HRT of a largescale CSTR could be adjusted flexibility. Based on this theory, for

Table 5

Kinetics results of food waste with different crude fat contents obtained using the modified Gompertz model.

\begin{tabular}{|c|c|c|c|c|c|c|c|c|c|}
\hline \multirow[t]{2}{*}{ Crude fat content (\%) } & \multirow[t]{2}{*}{ Fermentation concentration (gVS/L) } & \multirow[t]{2}{*}{$\mathrm{R}^{2}$} & \multirow[t]{2}{*}{$\mathrm{Rm}(\mathrm{mL} / \mathrm{gVS})$} & \multirow[t]{2}{*}{$\lambda$ (days) } & \multirow[t]{2}{*}{$\mathrm{T}_{90}$ (days) } & \multirow[t]{2}{*}{$\mathrm{T}_{\mathrm{ef}}$ (days) } & \multicolumn{3}{|c|}{ Cumulative methane yield (64 days) } \\
\hline & & & & & & & PM (mL/gVS) & MM (mL/gVS) & $\mathrm{DM}(\%)$ \\
\hline \multirow[t]{4}{*}{15} & 4 & 0.9862 & 39.3 & 1.3 & 21 & 19.7 & 495.6 & 507.6 & 2.4 \\
\hline & 6 & 0.9866 & 32.1 & 0.9 & 22 & 21.1 & 519.1 & 523.6 & 0.9 \\
\hline & 8 & 0.9970 & 41.8 & 2.0 & 20 & 18.0 & 544.1 & 550.1 & 1.1 \\
\hline & 10 & 0.9986 & 55.1 & 3.9 & 16 & 12.1 & 560.4 & 565.0 & 0.8 \\
\hline \multirow[t]{4}{*}{20} & 4 & 0.9887 & 36.9 & 1.1 & 22 & 20.9 & 534.3 & 549.1 & 2.7 \\
\hline & 6 & 0.9928 & 36.5 & 1.3 & 20 & 18.7 & 557.3 & 564.2 & 1.2 \\
\hline & 8 & 0.9978 & 40.0 & 3.3 & 23 & 19.7 & 573.2 & 580.2 & 1.2 \\
\hline & 10 & 0.9975 & 32.4 & 3.5 & 28 & 24.5 & 558.7 & 570.4 & 2.1 \\
\hline \multirow[t]{4}{*}{25} & 4 & 0.9835 & 32.1 & 0.4 & 26 & 25.6 & 569.3 & 583.5 & 2.4 \\
\hline & 6 & 0.9888 & 36.0 & 0.5 & 22 & 21.5 & 600.2 & 606.0 & 1.0 \\
\hline & 8 & 0.9990 & 30.9 & 3.6 & 27 & 23.4 & 575.2 & 575.2 & 0.0 \\
\hline & 10 & 0.9990 & 28.9 & 4.7 & 29 & 24.3 & 550.5 & 554.0 & 0.6 \\
\hline \multirow[t]{4}{*}{30} & 4 & 0.9930 & 40.1 & 1.8 & 23 & 21.2 & 620.0 & 630.2 & 1.6 \\
\hline & 6 & 0.9981 & 34.0 & 2.5 & 24 & 21.5 & 574.5 & 580.3 & 1.0 \\
\hline & 8 & 0.9990 & 27.9 & 4.7 & 28 & 23.3 & 543.8 & 541.6 & 0.4 \\
\hline & 10 & 0.9979 & 22.1 & 5.6 & 33 & 27.4 & 526.7 & 522.1 & 0.9 \\
\hline \multirow[t]{4}{*}{35} & 4 & 0.9993 & 34.2 & 3.4 & 26 & 22.6 & 568.9 & 573.0 & 0.7 \\
\hline & 6 & 0.9987 & 24.7 & 4.0 & 29 & 25.0 & 546.7 & 540.8 & 1.1 \\
\hline & 8 & 0.9976 & 22.2 & 5.0 & 30 & 25.0 & 543.5 & 530.6 & 2.4 \\
\hline & 10 & 0.9996 & 22.0 & 7.1 & 31 & 23.9 & 508.0 & 499.0 & 1.8 \\
\hline
\end{tabular}

$T_{90}$ - Time taken for $90 \%$ methane production.

$T_{e f}$ - Effective methane production duration $\left(T_{90}-\lambda\right)$.

PM: Predicted methane yield (mL/gVS)-64 days.

MM: Measure methane yield (mL/gVS)-64 days.

DM: Difference between measured and predicted methane yield (\%). 
a CF content in FW less than $20 \%$, the recommended HRT of largescale biogas plants for treating FW is around 20 days. However, in order to maintain digester operation stability and obtain a high biodegradable rate for FW with a high CF content, the HRT should be more than 30 days.

\section{Conclusions}

The optimum CF content and initial substrate concentration for $\mathrm{AD}$ were $30 \%$ at $4 \mathrm{gVS} / \mathrm{L}$ and $25 \%$ at $6 \mathrm{gVS} / \mathrm{L}$, which achieved high methane yields of 630.2 and $606.0 \mathrm{~mL} / \mathrm{gVS}_{\text {added }}$, respectively. The lag-time $(\lambda)$ increased as the CF content and initial substrate concentration increased from around 0.4 to 7.1 days. The results of this experiment will strongly provide basic scientific knowledge for a large-scale biogas plant using FW as the main material, which could adjust the operational load and HRT basis on the various output of FW and CF content in FW to achieve the maximum economic benefit.

\section{Acknowledgements}

This study was supported by the Non-Profit Research Foundation for Agriculture (Grant No. 201303091), and China Agriculture Research System (Grant No. CARS-36-10B).

\section{References}

Achinas, S., Euverink, G.J.W., 2016. Theoretical analysis of biogas potential prediction from agricultural waste. Resour. Efficient Technol. 2 (3), 143-147.

Angelidaki, I., Ahring, B., 1992. Effects of free long-chain fatty acids on thermophilic anaerobic digestion. Appl. Microbiol. Biotechnol. 37 (6), 808-812.

APHA, 2005. Standard Methods for the Examination of Water and Wastewater. Public Health Association, Washington, DC.

Banks, C.J., Zhang, Y., 2010. Optimising Inputs and Outputs From Anaerobic Digestion Processes Defra project Code WR0212* http://randd.defra.gov.uk/ Document.aspx.

Banks, C.J., Zhang, Y., Jiang, Y., Heaven, S., 2012. Trace element requirements for stable food waste digestion at elevated ammonia concentrations. Bioresour. Technol. 104, 127-135.

Bernat, K., Bialowiec, A., Wojnowska-Baryla, I., 2008. Co-fermentation of sewage sludge and waste from oil production. Archiwum Ochrony Srodowiska 34 (12) 103-114.

Borja, R., Rincón, B., Raposo, F., Domınguez, J., Millán, F., Martın, A., 2004. Mesophilic anaerobic digestion in a fluidised-bed reactor of wastewater from the production of protein isolates from chickpea flour. Process Biochem. 39 (12), 1913-1921.

Bruni, E., Jensen, A.P., Pedersen, E.S., Angelidaki, I., 2010. Anaerobic digestion of maize focusing on variety, harvest time and pretreatment. Appl. Energy 87 (7), 2212-2217.

Cho, H.S., Moon, H.S., Lim, J.Y., Kim, J.Y., 2013. Effect of long chain fatty acids removal as a pretreatment on the anaerobic digestion of food waste. J. Mater. Cycles Waste Manage. 15 (1), 82-89.

Cirne, D., Paloumet, X., Björnsson, L., Alves, M., Mattiasson, B., 2007. Anaerobic digestion of lipid-rich waste - effects of lipid concentration. Renewable Energy 32 (6), 965-975.

Dhar, H., Kumar, P., Kumar, S., Mukherjee, S., Vaidya, A.N., 2015. Effect of organic loading rate during anaerobic digestion of municipal solid waste. Bioresour. Technol. 217, 56-61.

Gelegenis, J., Georgakakis, D., Angelidaki, I., Christopoulou, N., Goumenaki, M., 2007. Optimization of biogas production from olive-oil mill wastewater, by codigesting with diluted poultry-manure. Appl. Energy 84 (6), 646-663.

Gumisiriza, R., Mshandete, A.M., Rubindamayugi, M.S.T., Kansiime, F., Kivaisi, A.K., 2009. Enhancement of anaerobic digestion of Nile perch fish processing wastewater. Afr. J. Biotechnol. 8 (2).

Kafle, G.K., Bhattarai, S., Sang, H.K., Chen, L., 2014. Effect of feed to microbe ratios on anaerobic digestion of Chinese cabbage waste under mesophilic and thermophilic conditions: biogas potential and kinetic study. J. Environ. Manage. 133, 293-301.

Kafle, G.K., Kim, S.H., 2013. Effects of chemical compositions and ensiling on the biogas productivity and degradation rates of agricultural and food processing by-products. Bioresour. Technol. 142, 553-561.

Kafle, G.K., Kim, S.H., Sung, K.I., 2013. Ensiling of fish industry waste for biogas production: a lab scale evaluation of biochemical methane potential (BMP) and kinetics. Bioresour. Technol. 127, 326-336.

Kafle, G.K., Sang, H.K., 2013. Anaerobic treatment of apple waste with swine manure for biogas production: batch and continuous operation. Appl. Energy 103 (1) $61-72$.

Karthikeyan, O.P., Visvanathan, C., 2012. Effect of C/N ratio and ammonia-N accumulation in a pilot-scale thermophilic dry anaerobic digester. Bioresour. Technol. 113, 294-302.

Khanal, S.K., 2008. Anaerobic Biotechnology for Bioenergy Production. WileyBlackwell, Iowa, p. 179

Kim, S.-H., Han, S.-K., Shin, H.-S., 2004. Kinetics of LCFA inhibition on acetoclastic methanogenesis, propionate degradation and $\beta$-oxidation. J. Environ. Sci. Health Part A 39 (4), 1025-1037.

Lalman, J.A., Bagley, D.M., 2004. Extracting long-chain fatty acids from a fermentation medium. J. Am. Oil. Chem. Soc. 81 (2), 105-110.

Li, Y., Jin, Y., Li, J., Li, H., Yu, Z., 2016. Effects of thermal pretreatment on the biomethane yield and hydrolysis rate of kitchen waste. Appl. Energy 172, 4758.

Neves, L., Oliveira, R., Alves, M., 2009. Fate of LCFA in the co-digestion of cow manure, food waste and discontinuous addition of oil. Water Res. 43 (20) 5142-5150.

Niu, Q., Qiao, W., Qiang, H., Hojo, T., Li, Y.-Y., 2013. Mesophilic methane fermentation of chicken manure at a wide range of ammonia concentration: stability, inhibition and recovery. Bioresour. Technol. 137, 358-367.

Noutsopoulos, C., Mamais, D., Antoniou, K., Avramides, C., Oikonomopoulos, P., Fountoulakis, I., 2013. Anaerobic co-digestion of grease sludge and sewage sludge: the effect of organic loading and grease sludge content. Bioresour. Technol. 131, 452-459.

Palatsi, J., Laureni, M., Andrés, M., Flotats, X., Nielsen, H., Angelidaki, I., 2009 Strategies for recovering inhibition caused by long chain fatty acids on anaerobic thermophilic biogas reactors. Bioresour. Technol. 100 (20), 45884596.

Pastor, L., Ruiz, L., Pascual, A., Ruiz, B., 2013. Co-digestion of used oils and urban landfill leachates with sewage sludge and the effect on the biogas production. Appl. Energy 107, 438-445.

Qiang, H., Lang, D.L., Li, Y.Y., 2012. High-solid mesophilic methane fermentation of food waste with an emphasis on Iron, Cobalt, and Nickel requirements. Bioresour. Technol. 103 (1), 21-27.

Raheman, H., Mondal, S., 2012. Biogas production potential of jatropha seed cake Biomass Bioenergy 37, 25-30.

Raposo, F., Borja, R., Martín, M., Martín, A., De la Rubia, M., Rincón, B., 2009. Influence of inoculum-substrate ratio on the anaerobic digestion of sunflower oil cake in batch mode: process stability and kinetic evaluation. Chem. Eng. J 149 (1), 70-77.

Rieger, C., Weiland, P., 2006. Prozessstörungen frühzeitig erkennen. Biogas J. 4 (06), $18-20$.

Rincón, B., Banks, C.J., Heaven, S., 2010. Biochemical methane potential of winter wheat (Triticum aestivum L.): influence of growth stage and storage practice. Bioresour. Technol. 101 (21), 8179-8184.

Sompong, O., Boe, K., Angelidaki, I., 2012. Thermophilic anaerobic co-digestion of oil palm empty fruit bunches with palm oil mill effluent for efficient biogas production. Appl. Energy 93, 648-654.

Wellinger, A., Murphy, J., Baxter, D., 2013. The Biogas Handbook: Science, Production and Applications.

Wu, X., Wei, K., Sha, S., Wang, J., Yuan, X., 2011. Present status and developing tren of kitchen garbage processing in China and abroad. Agric. Equipment Vehicle Eng. 126, 49-52 (in Chinese).

Zhang, J., Lv, C., Tong, J., Liu, J., Liu, J., Yu, D., Wang, Y., Chen, M., Wei, Y., 2016 Optimization and microbial community analysis of anaerobic co-digestion of food waste and sewage sludge based on microwave pretreatment. Bioresour. Technol. 200 (2), 253-261.

Zhang, W., Lang, Q., Wu, S., Li, W. Bah, H., Dong, R., 2014 Anaerobic digestion characteristics of pig manures depending on various growth stages and initial substrate concentrations in a scaled pig farm in Southern China. Bioresour Technol. 156, 63-69.

Zhang, Y., Dube, M., McLean, D., Kates, M., 2003. Biodiesel production from waste cooking oil: 1. Process design and technological assessment. Bioresour. Technol. 89 (1), 1-16. 